\title{
Fusarium Wilt of Banana Is Caused by Several Pathogens Referred to as Fusarium oxysporum f. sp. cubense
}

\author{
Randy C. Ploetz
}

University of Florida, IFAS, Department of Plant Pathology, Tropical Research \& Education Center, 18905 SW 280 th Street, Homestead 33031. Accepted for publication 6 December 2005.

\begin{abstract}
Ploetz, R. C. 2006. Fusarium wilt of banana is caused by several pathogens referred to as Fusarium oxysporum f. sp. cubense. Phytopathology 96:653-656.

Fusarium wilt of banana (also known as Panama disease) is caused by Fusarium oxysporum f. sp. cubense. Where susceptible cultivars are grown, management is limited to the use of pathogen-free planting stock and clean soils. Resistant genotypes exist for some applications, but resistance is still needed in other situations. Progress has been made with this

recalcitrant crop by traditional and nontraditional improvement programs. The disease was first reported in Australia in 1876, but did the greatest damage in export plantations in the western tropics before 1960. A new variant, tropical race 4 , threatens the trades that are now based on Cavendish cultivars, and other locally important types such as the plantains. Phylogenetic studies indicate that $F$. oxysporum f. sp. cubense had several independent evolutionary origins. The significance of these results and the future impact of this disease are discussed.
\end{abstract}

Bananas and plantains (a type of banana) are large monocotyledonous herbs from southern Asia $(6,28)$. With few exceptions, the parents of the cultivated bananas occur among two diploid, seeded species of Musa, M. acuminata Colla and M. balbisiana Colla (section Eumusa Cheesman, family Musaceae A.L. Jussieu, suborder Musineae W.J. Kress, and order Zingiberales Nakai) (14,28,30). The cultigens are landraces and are among the most important agricultural crops in the tropics $(2,10)$. Over 100 million metric tons of fruit is produced annually. Those that enter international commerce are worth $\$ 5$ billion per year, and locally consumed fruit are major staples for 400 million people in Africa and Latin America.

\section{THE DISEASE}

Fusarium wilt, which is also known as Panama disease, is the most important lethal disease of banana $(15,23,25,29,31,35)$.

Geographical distribution. Fusarium wilt probably originated in Southeast Asia, but was first reported in Australia in 1876 $(24,25)$. It is found in all banana-producing regions except the Mediterranean, Melanesia, Somalia, and some islands in the South Pacific $(1,25,31)$.

Symptoms. The first internal symptom, a reddish brown discoloration of the xylem, develops in feeder roots, the initial sites of infection $(25,31)$. Vascular discoloration progresses to the rhizome, is most prominent where the stele joins the cortex, and ultimately proceeds up to and includes large portions of the pseudostem. On plants that are more than 4 months old, the oldest leaves yellow or split longitudinally at the base. Eventually younger and younger leaves wilt and collapse until the entire canopy consists of dead or dying leaves.

Corresponding author: R. C. Ploetz; E-mail address: rcp@ifas.ufl.edu

DOI: 10.1094/PHYTO-96-0653

(c) 2006 The American Phytopathological Society
Epidemiology. Since infected rhizomes are often symptomless, they effectively spread the pathogen when used as seed pieces (31). The pathogen also moves in soil and running water, and on farm implements and machinery. It survives up to 30 years in the absence of banana, and nonhost weed species that are infected by the pathogen are reservoirs of inoculum $(31,38)$.

Management. Few options exist for managing this disease (25). Susceptible clones can be grown if pathogen-free propagation material, such as that from tissue culture, is used in clean soil. Long-term chemical and physical measures are not available. Disease-suppressive soils are known, but the conversion of disease-conducive soil to a suppressive condition has not been reported. To date, results from biological and cultural control studies have been disappointing (21).

Genetic resistance is the most effective and sustainable management option $(5,11,25,33)$. Pre-existing cultivars are available that perform well in different regions and against different populations of the pathogen. Resistant hybrids have been developed via conventional (breeding) and nonconventional (somaclonal selection) means. Efforts are underway to genetically transform important cultivars for resistance.

\section{THE PATHOGEN}

Fusarium oxysporum Schlectend.: Fr. is a species complex of morphologically similar filamentous fungi (17). It is comprised of mainly saprophytic strains, but also contains plant pathogens that cause vascular wilts, rots, and damping-off of hundreds of host species $(8,9,16)$. Agriculturally and economically, it is the most important taxon in Fusarium.

Over 150 special forms, formae speciales, of $F$. oxysporum are known (3). Each forma specialis has a unique host range of one or a usually closely related set of species. Fusarium wilt of banana is caused by $F$. oxysporum f. sp. cubense (E.F. Smith) Snyder \& Hansen.

Host range. F. oxysporum f. sp. cubense affects primarily banana and plantain, but other banana relatives are also susceptible. 
Abacá, M. textilis Née, source of an important cordage fiber, suffered considerable commercial losses before production ceased in Central America in 1956 (32,36). M. schizocarpa Simmonds is a parent of rare bananas in Papua New Guinea, whereas enset, Ensete ventricosum (Welw.) Cheesman, an important food crop in Ethiopia, is affected experimentally by an unusual member of F. oxysporum f. sp. cubense (described below; 20).

Waite (37) reported that several species of Heliconia were affected in Central and South America in the mid-1900s; he named the causal strains race 3 of $F$. oxysporum f. sp. cubense. Unfortunately, Waite did not deposit strains of race 3 in culture collections and wilted heliconias have not been found in the Americas since his original report. Recently, an outbreak of Fusarium wilt on $H$. chartacea in Australia was caused by a unique population of $F$. oxysporum $(4,15)$; whether it is endemic or American is not known.

Morphology. In general, strains of $F$. oxysporum cannot be distinguished morphologically $(8,9,16)$. Colonies grow 4 to $7 \mathrm{~mm}$ day $^{-1}$ on potato dextrose agar at $24^{\circ} \mathrm{C}$, with usually abundant aerial, white to purple mycelium. Sporodochia are tan to orange, and sclerotia are blue and submerged. Micro- and macroconidia are produced on branched and unbranched monophialides. Microconidia are 5 to $16 \times 2.4$ to $3.5 \mu \mathrm{m}$, one- or two-celled, oval- to kidney-shaped, and are borne in false heads. Macroconidia are 27 to $55 \times 3.3$ to $5.5 \mu \mathrm{m}$, four- to eight-celled, and sickle-shaped with foot-shaped basal cells. Terminal and intercalary chlamydospores are 7 to $11 \mu \mathrm{m}$ in diameter, usually globose and are formed singly or in pairs in hyphae or conidia. Chlamydospores are not produced by isolates in vegetative compatibility group (VCG) 01214 of F. oxysporum f. sp. cubense. F. oxysporum f. sp. cubense has no known teleomorph.

Race. Race has been used to classify strains of $F$. oxysporum $\mathrm{f}$. sp. cubense since the mid-1900s (31). Although it is an imperfect measure of pathogenic diversity in this complex, it does, nonetheless, provide useful information. Traditionally, the following cultivars have been used as differentials: 'Gros Michel' race 1; 'Bluggoe' race 2; and 'Cavendish' race 4. (Since Waite's [37] and the Australian heliconia strains do not affect banana, race 3 could be considered a distinct forma specialis, heliconiae [15,22].) Also affected by race 1 are abacá, 'Maqueño', 'Silk', 'Pome', and 'Pisang Awak'; by race 2, some bred tetraploids and enset; and race 4 , race 1 and race 2 suscepts, plantains, and assorted dessert and cooking cultivars (25).

Race 4 had been considered a subtropical problem (cold temperatures predispose the normally resistant Cavendish cultivars) (23). However, in the early 1990s, Cavendish plantations in tropical Southeast Asia began to experience serious losses $(21,25,26)$. A new variant of $F$. oxysporum $\mathrm{f}$. sp. cubense, tropical race 4 (VCG 01213-01216), is responsible. It is still restricted to Asia and northern Australia, but has caused grave concern in the western Cavendish-dependent export trades and wherever plantains are important local foods.

Genetic diversity, phylogeny, and reproductive strategies. Diverse phenetic and genetic characters have been used to study variation in $F$. oxysporum f. sp. cubense $(20,25)$. Significant progress to understand the population biology of $F$. oxysporum f. sp. cubense resulted after the development of a straight-forward method for determining VCGs in the late 1980s (7,27), and over 20 VCGs of $F$. oxysporum f. sp. cubense have been reported to date (25). The phylogenies of these populations were investigated in the following decade.

Koenig et al. (13) studied 165 strains in 13 VCGs/VCG complexes with restriction fragment length polymorphisms (RFLPs) of genomic DNA and 19 anonymous, single-copy DNA probes. Nine polymorphic RFLP loci and 72 unique genotypes were identified, and about half of the strains were represented by 5 of the 72 genotypes. Using parsimony analysis of the RFLP data, several clonal lineages were delineated. Surprisingly, lineage I (corresponded to VCG 0124-0125-0128 complex) and lineage II (VCG 0120-01215) were genetically more similar to $F$. oxysporum f. sp. niveum, a pathogen of watermelon, than to each other, and were as closely related to each other as they were to $F$. oxysporum f. sp. lycopersici, a pathogen of tomato.

Lineage V (VCG 01214, found only in a small area in Malawi) was genetically distinct from all other $F$. oxysporum $\mathrm{f}$. sp. cubense lineages. Isolates in lineage $\mathrm{V}$ affect enset, a musaceous plant that is endemic to Africa, as well as the race 2 suscept, 'Bluggoe' (R. C. Ploetz, unpublished data). Unlike other F. oxysporum f. sp. cubense lineages that likely coevolved with banana in Southeast Asia, lineage $\mathrm{V}$ may have evolved in Africa (24).

O'Donnell et al. (18) constructed genealogies for nuclear (translation elongation factor $1 \alpha$ ) and mitochondrial (mt small subunit ribosomal RNA) genes of 23 F. oxysporum $\mathrm{f}$. sp. cubense isolates that represented unique RFLP genotypes identified by Koenig et al. (13), and two or more individuals of $F$. oxysporum ff. spp. lycopersici, melonis, and radicis-lycopersici. For the F. oxysporum f. sp. cubense isolates, there was complete agreement between the sequence phylogenies and those that were determined during the RFLP study. Significantly, parsimony analyses of the combined sequence data indicated that none of the formae speciales that were examined were monophyletic (i.e., had common evolutionary origins). This was the first time that formae speciales of $F$. oxysporum were shown to be para- or polyphyletic, a surprising conclusion given prior assumptions that members of a forma speciales must be closely related.

Subsequent phylogenetic studies have shown that the morphological species concept for $F$. oxysporum appears to be so broad that it is practically meaningless $(12,17)$. Moreover, the forma specialis concept is phylogenetically misleading; in fact, multiple evolutionary histories are now known to be fairly common in formae speciales of $F$. oxysporum $(3,12,13,17)$. This has important implications for understanding these important plant pathogens, and for the development and deployment of resistant genotypes of host plants.

Since a teleomorph has not been observed for $F$. oxysporum f. sp. cubense, it had been assumed that it reproduced clonally. Koenig et al. (13) provided genetic evidence that supported this assumption. Gametic disequilibrium was shown to be significantly nonrandom among pairs of 34 of 36 RFLP alleles, and strains with identical genotypes were found worldwide. Furthermore, a strong correlation was recognized among independent genetic markers. Thus, F. oxysporum f. sp. cubense apparently has a predominantly or exclusively clonal population structure.

Taylor et al. (34) reanalyzed some of the RFLP data of Koenig et al. (13). They noted that in one of the largest clades identified by Koenig et al. (13) (it contained lineage I and lineage VIII) there was little resolution and only one internal branch, which was consistent with recombination. Taylor et al. (34) used two different statistical tests, the index of association $\left(I_{A}\right)$ and the parsimony tree length permutation test (PTLPT), to determine whether alleles in this clade were recombining or were inherited clonally. By examining only the 25 unique genotypes in the lineage I + lineage VIII clade, they found no statistical support that its members reproduced in a strictly clonal fashion. Probabilities for the hypothesis that this population was significantly different from one that was recombining $=0.83$ for the $I_{A}$ index and 0.85 for the PTLPT index. Unfortunately, these tests do not indicate what mechanism(s) of recombination are involved. Either parasexuality or sexual recombination may be operating in lineages I and VIII but it is unclear whether such processes are ongoing or whether the results indicate historical recombination.

\section{DISCUSSION}

Due to its impact on the 'Gros Michel'-based export trades, Fusarium wilt was the most important disease of banana until 
$1960(11,23,25,31)$. With the conversion to the Cavendish cultivars, Fusarium wilt was no longer a problem in the tropical trades. It remained important only where Cavendish was affected in the subtropics and on other, less important cultivars.

The appearance of tropical race 4 in Southeast Asia has changed this assessment $(21,26)$. Once again, the banana on which the export trades depend is threatened with destruction by Fusarium wilt. Also affected are the important plantain cultivars that feed some 400 million people, as well as numerous cooking and dessert cultivars. In total, approximately $80 \%$ of the bananas that are produced are susceptible, and many of these are not affected by other races of $F$. oxysporum f. sp. cubense. Since tropical race 4 threatens both export production and food security, activities to monitor its spread and develop contingency plans for its arrival in other areas should be started as soon as possible.

Considering the long-term survival of $F$. oxysporum f. sp. cubense in soil, the absence of effective biological, chemical, and physical control measures, and the susceptibility of many otherwise desirable cultivars, Fusarium wilt is a most difficult problem. Thus, the development of new, resistant genotypes is of great importance $(5,25)$. The breeding programs face significant hurdles, including fertility problems among desirable parents, low viability of hybrid progeny, inadequate agronomic attributes of the resistant parents, and poor organoleptic and postharvest traits among resistant hybrids that have been developed thus far. Given these problems, nonconventional approaches have received much attention, especially when the breeding target is sterile and has exceptionally good yield and market characteristics (e.g., the Cavendish subgroup). Interested readers are referred to a recent summary (11).

Reports of phylogenetically diverse formae speciales of $F$. oxysporum are recent but increasingly common $(3,12,13,17)$. That some lineages of $F$. oxysporum f. sp. cubense are more closely related to other formae speciales of $F$. oxysporum than to other lineages of $F$. oxysporum f. sp. cubense has direct relevance to understanding this pathogen and to the management of the important disease it causes. Different lineages of F. oxysporum f. sp. cubense affect different banana cultivars (25), and the underlying genes for resistance in banana and virulence in $F$. oxysporum $\mathrm{f}$. sp. cubense may differ in each situation (12). Since different resistances have been used to combat different lineages of $F$. oxysporum f. sp. cubense $(19,33)$, new parents may be needed to address tropical race 4 and other pathotypes of $F$. oxysporum f. sp. cubense that arise in the future. The identification and utilization of new resistances should receive a high priority.

\section{ACKNOWLEDGMENTS}

This review is dedicated to the memories of four pioneers in banana improvement and pathology, Phillip Rowe (1939-2001), Kenneth Shepherd (1937-2001), Norman Willison Simmonds (1922-2002), and Robert Harry Stover (1926-2003). This is Florida Agricultural Experiment Station Journal Series R-10976.

\section{LITERATURE CITED}

1. Anonymous. 1977. Fusarium oxysporum f. sp. cubense, Distribution Maps of Plant Diseases. Map No. 31, 4th ed. Commonwealth Mycological Institute, Kew, England.

2. Anonymous. 2005. FAOSTAT. FAO Statistical Database. http://www.fao.org/

3. Baayen, R. P., O’Donnell, K., Bonants, P. J. M., Cigelnik, E., Kroon, L. P. N. M., Roebroeck, E. J. A., and Waalwijk, C. 2000. Gene genealogies and AFLP analyses in the Fusarium oxysporum complex identify monophyletic and nonmonophyletic formae speciales causing wilt and rot disease. Phytopathology 90:891-900.

4. Bentley, S., Pegg, K. G., Moore, N. Y., Davis, R. D., and Buddenhagen, I. W. 1998. Genetic variation among vegetative compatibility groups of Fusarium oxysporum f. sp. cubense analyzed by DNA fingerprinting. Phytopathology 88:1283-1293.
5. Buddenhagen, I. W. 1990. Banana breeding and Fusarium wilt. Pages 107-113 in: Fusarium Wilt of Banana. R. C. Ploetz, ed. The American Phytopathological Society, St. Paul, MN.

6. Carreel, F., Fauré, S., González de León, D., Lagoda, P. J. L., Perrier, X., Bakry, F., Tezenas du Montcel, H., Lanaud, C., and Horry, J. P. 1994. Evaluation de la diversité génétique chez les bananies diploides (Musa spp.). Genet. Sel. Evol. 26:125s-136s.

7. Correll, J. C., Klittich, C. J. R., and Leslie, J. F. 1987. Nitrate-nonutilizing mutants of Fusarium oxysporum and their use in vegetative compatibility tests. Phytopathology 77:1640-1646.

8. Domsch, K. H., Gams, W., and Anderson, T.-H. 1980. Compendium of Soil Fungi, Vol. 1. Academic Press, New York.

9. Gerlach, W., and Nirenberg, H. 1982. The Genus Fusarium-A Pictorial Atlas. Paul Parey, Berlin, Germany.

10. International Network for the Improvement of Banana and Plantain (INIBAP). http://www.inibap.org/index.php?page=home->bp

11. Jones, D. R. (ed.) 2000. Diseases of Banana, Abacá and Enset. CABI Publishing, Wallingford, UK.

12. Kistler, H. C. 2001. Evolution of host specificity in Fusarium oxysporum. Pages 70-82 in: Fusarium: Paul E. Nelson Memorial Symposium. The American Phytopathological Society, St. Paul, MN.

13. Koenig, R., Ploetz, R. C., and Kistler, H. C. 1997. Fusarium oxysporum f. sp. cubense consists of a small number of divergent and globally distributed lineages. Phytopathology 87:915-923.

14. Kress, W. J. 1990. The phylogeny and classification of the Zingiberales. Ann. Mo. Bot. Gard. 77:698-721.

15. Moore, N., Pegg, K. G., Buddenhagen, I. W., and Bentley, S. 2001. Fusarium wilt of banana: A diverse clonal pathogen of a domesticated clonal host. Pages 212-224 in: Fusarium: Paul E. Nelson Memorial Symposium. B. A. Summerell, J. F. Leslie, D. Backhouse, W. L. Bryden, and L. Burgess, eds. The American Phytopathological Society, St. Paul, $\mathrm{MN}$.

16. Nelson, P. E., Toussoun, T. A., and Marasas, W. O. 1983. Fusarium Species. An Illustrated Guide for Identification. Pennsylvania State University Press, University Park.

17. O'Donnell, K., and Cigelnik, E. 1999. A DNA sequence-based phylogenetic structure for the Fusarium oxysporum species complex. Phytoparasitica 27:69.

18. O’Donnell, K. O., Kistler, H. C., Cigelnik, E., and Ploetz, R. C. 1998. Multiple evolutionary origins of the fungus causing Panama disease of banana: Concordant evidence from nuclear and mitochondrial gene genealogies. Proc. Natl. Acad. Sci. USA 95:2044-2049.

19. Ortiz, R. 1995. Musa genetics. Pages 84-109 in: Bananas and Plantains. S. Gowen, ed. Chapman \& Hall, London, UK.

20. Ploetz, R. 2001. The phylogenies and reproductive strategies of globally dispersed populations of Fusarium oxysporum f. sp. cubense. Pages 133142 in: Banana Fusarium Wilt Management: Towards Sustainable Cultivation. A. B. Molina, N. H. N. Masdek, and K. W. Liew, eds. International Network for the Improvement of Banana and Plantain. Los Baños, Philippines.

21. Ploetz, R. 2004. Diseases and pests: A review of their importance and management. INFOMUSA 13(2):11-16.

22. Ploetz, R., and Bentley, S. 2001. Workshop reports. Pathogen diversity. Pages 293-294 in: Banana Fusarium Wilt Management: Towards Sustainable Cultivation. A. B. Molina, N. H. N. Masdek, and K. W. Liew, eds. International Network for the Improvement of Banana and Plantain. Los Baños, Philippines.

23. Ploetz, R. C. (ed.) 1990. Fusarium Wilt of Banana. The American Phytopathological Society, St. Paul, MN.

24. Ploetz, R. C., and Pegg, K. G. 1997. Fusarium wilt of banana and Wallace's line: Was the disease originally restricted to his Indo-Malayan region? Australas. Plant Pathol. 26:239-249.

25. Ploetz, R. C., and Pegg, K. G. 2000. Fusarium wilt. Pages 143-159 in: Diseases of Banana, Abacá and Enset. D. R. Jones, ed. CABI Publishing, Wallingford, UK.

26. Ploetz, R. C., Thomas, J. E., and Slabaugh, W. 2003. Diseases of banana and plantain. Pages 73-134 in: Diseases of Tropical Fruit Crops. R. C. Ploetz, ed. CABI Publishing, Wallingford, UK.

27. Puhalla, J. E. 1985. Classification of strains of Fusarium oxysporum on the basis of vegetative compatibility. Can. J. Bot. 63:179-183.

28. Simmonds, N. W. 1962. The Evolution of the Bananas. Longmans, London, UK.

29. Simmonds, N. W. 1966. Bananas. 2nd ed. Longmans, London, UK.

30. Simmonds, N. W., and Shepherd, K. 1955. Taxonomy and origins of cultivated bananas. J. Linn. Soc. Bot. (London) 55:302-312.

31. Stover, R. H. 1962. Fusarial Wilt (Panama Disease) of Bananas and Other Musa Species. Commonwealth Mycological Institute, Kew, England.

32. Stover, R. H. 1972. Banana, Plantain, and Abaca Diseases. Commonwealth Mycological Institute, Kew, England.

33. Stover, R. H., and Buddenhagen, I. W. 1986. Banana breeding: Poly- 
ploidy, disease resistance and productivity. Fruits 41:175-191.

34. Taylor, J. W., Jacobson, D. J., and Fisher, M. C. 1999. The evolution of asexual fungi: Reproduction, speciation and classification. Annu. Rev. Phytopathol. 37:197-246.

35. Thurston, H. D. 1997. Tropical Plant Diseases. 2nd ed. The American Phytopathological Society, St. Paul, MN.
36. Waite, B. H. 1954. Vascular disease of abaca or Manila hemp in Central America. Plant Dis. Rep. 38:575-578.

37. Waite, B. H. 1963. Wilt of Heliconia spp. caused by Fusarium oxysporum f. sp. cubense race 3. Trop. Agric. (Trinidad) 40:299-305.

38. Waite, B. H., and Dunlap, V. C. 1953. Preliminary host range studies with Fusarium oxysporum f. sp. cubense. Plant Dis. Rep. 37:79-80. 